DOI https://doi.org/10.51647/kelm.2020.3.2.4

\title{
TRADITIONS AND INNOVATIONS OF RELIGIOUS CHOIR WORKS BY V. STEPURKO
}

\author{
Maryna Varakuta \\ PhD in Arts, Associated Professor, \\ Professor at the Department of History and Theory of Music \\ M. Glinka Dnipropetrovsk Academy of Music of Dnipropetrovsk Regional Council \\ ORCID ID: 0000-0003-0863-8829
}

\begin{abstract}
The purpose of the work. The article studies, on the example of the creative work of the famous Ukrainian composer Viktor Stepurko, the problem of the correlation of traditions and innovations in modern choral works of religious subject, created over the past two decades. It is noted that choral music occupies an important place in V. Stepurko's work, and that the composer pays considerable attention to a religious theme, which gives us every reason to study the stylistic features of the creative method and the most important principles of religious choral works in the context of Ukrainian music of the late XX - early XXI century. The methodology of the research is a historical-typological method and a genrestyle one. The historical-typological method is associated with the problems of the historical evolution of the Ukrainian religious music, the genre-style method is associated with the issues of a contemporary music analysis. The scientific novelty of the work is in the study of well-known but little-investigated compositions for a choir, created by the modern Ukrainian composer, and in which the traditions of the Ukrainian religious music are interpreted, and, at the same time, the modern trends of the musical language are clearly manifested. It is noted that the degree of correlation between traditions and innovations is determined by the individual creative approach of the composer, who has the need to refer to religious texts and create original chants on their basis. The conclusions indicate that the subject of the article can be continued on the material of religious choral works written by modern Ukrainian composers over the past two decades.

Key words: traditions, innovations, creative work of Viktor Stepurko, choral music, religious subject, psalm texts.
\end{abstract}

\section{ТРАДИЦІЇ ТА НОВАТОРСТВО ДУХОВНИХ ХОРОВИХ ТВОРІВ В. СТЕПУРКА}

\author{
Марина Варакута \\ кандидат мистецтвознавства, доцент, \\ професор кафедри історії і теорії музики \\ КЗВО «Дніпропетровська академія музики імені Михайла Глінки» Дніпропетровської обласної ради» \\ ORCID ID: 0000-0003-0863-8829
}

\begin{abstract}
Мета роботи. У статті на прикладі творчості відомого українського композитора Віктора Степурка вивчається проблема співвідношення традицій і новаторства у сучасних хорових творах духовної тематики, написаних протягом двох останніх десятиліть. Зазначається, що хорова музика посідає важливе місце у творчості В. Степурка, що композитор приділяє значну увагу духовній тематиці, що дає нам всі підстави для вивчення стильових особливостей творчого методу та найважливіших принципів духовної хорової творчості в контексті української музики кінця XX - початку XXI століття. Методологія дослідження грунтується на історико-типологічному та жанровостильовому методах. Історико-типологічний метод пов'язаний із проблемами історичної еволюції української духовної музики, жанрово-стильової - 3 питаннями аналізу сучасної музики. Наукова новизна роботи полягає у вивченні відомих, але малодосліджених композицій для хору, написаних сучасним українським композитором, у яких переломлюються традиції української духовної музики та водночас яскраво проявляються сучасні тенденції музичної мови. Зазначається, що міра співвідношення традицій і новаторства визначається індивідуальним творчим підходом композитора, який має потребу звернення до духовних текстів та створення на їх основі оригінальних піснеспівів. У висновках вказано, що тематика статті може бути продовжена на матеріалі духовних хорових творів, написаних сучасними українськими композиторами протягом двох останніх десятиліть.

Ключові слова: традиції, новаторство, творчість Віктора Степурка, хорова музика, духовна тематика, тексти псалмів.
\end{abstract}

TRADYCJE I INNOWACYJNOŚĆ DUCHOWYCH UTWORÓW CHÓRALNYCH V. STEPURKA

\author{
Maryna Varakuta \\ kandydat historii sztuki, docent, \\ profesor Katedry Historii i Teorii Muzyki \\ Uczelni spótdzielczej „,Dniepropetrowska Akademia Muzyczna \\ im. Michaiła Glinki” Dniepropetrowskiej Rady Obwodowej” \\ ORCID ID: 0000-0003-0863-8829
}

Cel pracy. Artykuł na przykładzie twórczości słynnego ukraińskiego kompozytora Viktora Stepurka bada problem stosunku tradycji i innowacyjności we współczesnych utworach chóralnych o tematyce duchowej, napisanych w ciągu 
ostatnich dwóch dekad. Należy zauważyć, że muzyka chóralna zajmuje ważne miejsce w twórczości V. Stepurka, a kompozytor zwraca szczególną uwagę na tematy duchowe, co zapewnia nam wszelkie podstawy do badania cech stylu metody twórczej i najważniejszych zasad duchowej twórczości chóralnej w kontekście ukraińskiej muzyki końca XX - początku XXI wieku. Metodologia badania opiera się na metodach historyczno-typologicznych i gatunkowostylowych. Metoda historyczno-typologiczna związana jest z problemami historycznej ewolucji ukraińskiej muzyki duchowej, gatunkowo-stylowa - z zagadnieniami analizy muzyki współczesnej. Nowość naukowa pracy polega na badaniu znanych, ale mało zbadanych kompozycji na chór, napisanych przez współczesnego ukraińskiego kompozytora, w których tradycje ukraińskiej muzyki duchowej są załamane, a jednocześnie współczesne trendy języka muzycznego są wyraźnie widoczne. Należy zauważyć, że miara stosunku tradycji do innowacyjności zależy od indywidualnego podejścia twórczego kompozytora, który musi odwoływać się do tekstów duchowych i tworzyć na ich podstawie oryginalne śpiewy. Wnioski wskazują, że tematyka artykułu może być kontynuowana na materiale duchowych utworów chóralnych napisanych przez współczesnych kompozytorów ukraińskich w ciaggu ostatnich dwóch dekad.

Słowa kluczowe: tradycje, innowacyjność, twórczość Viktora Stepurka, muzyka chóralna, tematyka duchowa, teksty psalmów.

Introduction. The relevance of the research topic. The famous Ukrainian composer, Honored Art Worker of Ukraine, the Shevchenko National Prize winner, Recipient of the Order of St. Vladimir, $3^{\text {rd }}$ Class, Victor Stepurko is recognized for his active creative work in the field of choral art. The composer's choral work has an attractive force and energy, revealing important points of intersection with the most significant phenomena of modern Ukrainian musical culture. That is why in recent decades there is a need for a musicological study of the composer's creative heritage. Meanwhile, there is no monographic literature devoted to this issue, one can find only a small number of reviews and interviews in media articles and publications. This article for the first time considers V. Stepurko's religious music, which occupies a prominent place in the contemporary choral art of Ukraine, as a valuable field of his heritage, and determines the relevance of the research and has a novelty factor.

The aim of the research is to identify the stylistic features of the composer, as well as the most important principles of his religious choral art in the context of Ukrainian music of the late XX - early XXI century.

The analysis of research and publications. Mainly critical journalistic articles, published on the pages of the periodical press (Verstiuk; Dnieper truth, 2012; Stepanchenko, 2012:6) or in popular science journals (Voloshyna, 2005: 3-4; Kushniruk, 2005: 13-15; Lunina, 2012: 24-27; Stepurko, 2007: 10-11), elucidated the creative work of V. Stepurko for a long time. Recently, the creative work of V. Stepurko has attracted the attention of the authors of scientific articles (Afonina, 2007: 146-155; Voloshyna, 2005: 178-187) and thesis researchers (Bardashevska, 2017). However, the published materials do not fully exhaust all the problems of the composer's work.

The scientific novelty of the work is in the study of well-known but little-investigated compositions for a choir, created by the modern Ukrainian composer, in which the traditions of Ukrainian religious music are interpreted, and, at the same time, the modern trends of the musical language are clearly manifested. At the same time, the degree of correlation between traditions and innovations is determined by the individual creative approach of the composer, who has the need to refer to religious texts and create original chants on their basis.

The basis matter. Victor Stepurko is the author of more than a hundred works in a wide range of genres. Some of them are: the opera "Passing Through" (after V. Shukshin), the modern ballet "The Glass Bead Game" (after H. Hesse), five grand opuses in the genre created by V. Stepurko himself and deserving separate consideration - "Symphonic Drama". The composer has created a huge number of vocal-symphonic, vocal-instrumental pieces and vocal compositions accompanied by an orchestra of folk instruments, a suite for chamber orchestra, harp and Glockenspiel, two sonatas for viola and piano, a poem for trumpet and piano, and many others. However, "recognition” of V. Stepurko's composer's style is undoubtedly connected with the dominant field of his creative work - this is choral religious music based on the thousand-year tradition of the Orthodox Church and the texts of prayers. Only in recent decades, the author has created more than ten Psalms of David, a number of religious cantatas, the dramatized mystery "The Prophecy on the Jesus' Sufferings and His Glory", the cycle "Monologues of Centuries", "Concert" in memory of M. Leontovich and many other choral works. Exactly the works like these open a new direction at the end of XX century, the tasks of which include reviving and developing of religious-musical ideas, which are genetically inherent in cultural consciousness. However, if the art of the beginning of the last century marked the search for "ecclesiasticism" through creative understanding and interpretation of the ancient liturgical and singing layers, the "newest direction" turns into the realization of a religious theme in music with a high degree of personal relation to it, in other words, with a significant preponderance of the author's individual creativity.

One of the most striking manifestations of this approach is the creation of an amount of choral compositions, the temple performance of which is impossible due to the use of solo instruments in them. This principle plays an important role in the creative work of V. Stepurko, however, it also applies to many of his contemporaries (L. Dychko's "Swiss Frescos"; solo and choral composition is completed by the organ and percussion instruments). In the works of V. Stepurko, this technique becomes one of the decisive. Thus, in Psalm 136 ("Give thanks to the Lord") the author uses the saxophone solo; Psalm 24 ("The earth is the Lord's") is written for the flute solo; in Psalm 8 ("O Lord, our Lord"), the solo violin transfers this composition into the category of concert.

A chorus "Blessed is the man" (Psalm 1) can be rightly called as a unique example of a new reading of the ancient canon. His sacred text is an introduction to the entire Psalter in general. It has a special place among other psalms. Its composition was attributed to David; it is indicated in the Church Slavonic text and in the synodal translation of the Bible.

The important thing is that V. Stepurko in strict accordance with the tendency of the Ukrainian spiritual Renaissance of the last two decades, not only uses the Ukrainian-language translation of the text of the psalm, but also brings it closer to modern vocabulary: 
Blessed is the man who walks not in the counsel of the wicked,

Nor stands in the way of sinners,

But his delight is in the law of the Lord,

He is like a tree planted by streams of water,

That yields its fruit, he prospers.

The wicked are not so, but the chaff

That the wind drives away.

For knows the way of the righteous,

But the way of the wicked will perish.

However, the unique originality of the psalm, in V. Stepurko's interpretation, roots in another thing. The work is written for mixed choir and the duduk solo. The composer combines three factors simultaneously: the ancient Znamenny chant, the archaic solo instrument and the text of the prayer.

In the chorus "Blessed is the man", the musical image is born from the first bars - a long bass organ point, and a tenor pedal (men's voices are sung with a closed mouth), creating, in combination with a slow tempo, a feeling of static. One constantly emphasizes the reliance on the diatonic ancient church modes. Beginning in the introduction, the solo duduk intones an ancient chant, characterized by a narrow range, repetition of tones and rotation around the reference sounds. It is the theme that later forms the basis of the choir vertical, being subjected to the constant variation. It is worth noting that Znamenny chant perfectly corresponds to the nature of the duduk, with its low mobility and limited range (from "fis" of the first octave to " $a$ " of the second one).

Gradually, the melodic line becomes chromatic, bringing some drama to the choir. In the $7^{\text {th }}$ bar of introduction, the duduk gets a reduced $6^{\text {th }}$ degree $B d u r-$ ges moll (a sign of harmonic major), giving a certain intensity to the melody. The sound as, added later, emphasizes the diatonic modal nature of the musical material and the Mixolydian mood of the theme (bars 16-28). Only in the final section (bars 34-47), dissonant low-second songs sound. In general, the chorus is inherent in modal variability in combination with the plagality, as well as beauty and softness of the harmonic vertical. Even though the tonal center is $B$, the last consonance is the es-moll chord of the sixth, which gives the composition a sense of tonal openness. The composition of the chorus is marked by prevailing continuous development, where the improvisational composition manifests itself through fluidity and ceaseless movement. The harmoniousness, proportionality, symmetry and simplicity of presentation correspond to the general nature of the prayer.

A chorus "O Lord, our Lord" (Psalm 8) includes a violin and its musical material is based on the prayer text, dedicated to praising God by David:

O Lord, our Lord,

How majestic is your name in all the earth.

You have set your glory above the heavens.

When I look at your heavens, the work of your fingers,

The moon and the stars, which you have set in place,

What is man that you are mindful of him,

And the son of man that you care for him?

Yet you have made him a little lower than the heavenly beings

And crowded him with glory and honor.

O Lord, our Lord,

How majestic is your name in all the earth.

The three-part structure, laid down in the text, predetermines the compositional characteristics of the chorus. Regardless of the end-to-end development, which is typical for the majority of V. Stepurko's works, the chorus "O Lord, Our God" is marked by a thematic setting that gives the features of a simple three-part reprise form.

The main theme originates from the top of the source, moving downwards with a consecutive downward introduction of voices (soprano - alto - tenor - bass), which gives the chorus a sense of illusiveness, ephemerality, weightlessness. The composer also chooses the dynamics (various aspects of piano), characteristic of "quiet" music; resorts to receiving choral divisi, which, in combination with the solo soprano, determines the transparency and softness of the texture.

The uniqueness of the chorus is associated with the use of a solo violin, which transfers this composition into a category of concert. It is the string instrument that endows the psalm with sounding unreality (in the framing sections, the violin sounds in the fourth octave as $p$ and $p p$ ). Harmonic vertical, with its sharpened chromatic, in some places with polytonality, becomes significant. Such a complicated structure is created by the solo instrument, as if in opposition to the choir. Also, it is worth observing that all choral voices are written out extremely strictly, and elements of chance music appear in the violin part (bar 49), as evidenced by the author's remark: "The number of repetitions is up to performer's wish". The peculiarity of the interpretation of choral parts, written purely instrumentally and sounding as specific orchestral timbres, distinguishes the chorus "O Lord, Our God" as well as the most of the choral compositions of V. Stepurko.

Another example of the modern view on the ancient church canon is the chorus "Save Me, O God" (Psalm 68). Among the huge poetic text (37 verses), the composer selects only those sections $(2,3,5,8,10-12,14,16-18)$ that are related to the tragic author's monologue:

Save me, O God! For the waters have come up to my neck.

When I wept my soul with fasting... 
Answer me... hide not your face...

For zeal for your house has consumed me,

And the reproaches of those who reproach you...

Let not the flood sweep over me, or the deep swallow me up...

I sink in deep mire...

More in number than the hairs on my head are

Those who hate me without cause...

But as for me, your prayer is to you...

When I made sackcloth my clothing,

I became a byword...

Answer me, O Lord...

In this chorus, the composer finds a musical solution that perfectly matches the meaning of the prayer text. Based on the traditional tonal technique, V. Stepurko rejects modern means (polytonality, chance music, diatonic and chromatic modalities), and the tragic moments in the chorus are achieved and strengthened by an unusual tonal-harmonic logic.

The composition of the chorus has two-part structure, and sections textually oppose each other: the first part bases on a homophonic-harmonic texture, with a strongly marked melodic line and a chord vertical; and the second one is a dramatic fugato. The composer avoids squareness by applying "torn" phrasing, e. g. the number of bars in each subsequent phrase changes: $3+2+3+3+2$. The main quality of the harmonic vertical of the first part is the abundance of descending suspensions, intonations of "sigh", causing the tragic nature of the work. Clear, regular metrics (size $6 / 4$ ), rhythmic regularity, and textured unity help to achieve the feeling of relative stability.

The second part introduces not only a bright textured contrast, but also becomes the embodiment of the universal, more than personal, which is replaced by the individual beginning prevailing in the first part of the chorus. The direction of the melodic motion is different - the descending movement in the first part changes to ascending one, which gives the fugato greater determination (Agitato). Metrics gives a special instability and impetuosity (the second part is written in the size of 5/4). A constructive solution of the fugato is interesting and peculiar as it has two-part structure with sections $(21+20)$ that are approximately equal in scale; in the exposition part, the composer gives an octave ratio of issue and answer. In the free part of fugato (bars 34-53), a stretta presentation arises, the theme appears in the modified quint development (in tenors, bar 40), and in inversion as well (altos, bar 36). Both ranges of singing voices and dynamics are marked with averageness, revealing not so much the volume and power of sound, as dramatic direction.

A deep and genuine drama and the continuity of end-to-end dramatic development distinguish the psalm "Save Me, O God" and determine the high ethical point of this work.

Conclusions and prospects for further investigations. Thus, the choral religious creative work of V. Stepurko is an important characteristic component of the modern view of the thousand-year tradition, which actively develops in XXI century, as evidenced by the composer's reference to religious texts and the creation on their basis of works filled with deep sacral meaning, but existing in modern culture. The subject of the article can be continued on the material of religious choral works written by modern Ukrainian composers over the past two decades.

\section{Bibliography:}

1. Афоніна О. Творчість В. Степурка у культурологічних вимірах сучасного музичного мистецтва. Мистецтвознавчі записки : збірник наукових праць. Київ : Міленіум, 2007. Вип. 11. С. 146-155.

2. Бардашевська Я.М. Образно-семантичні засади хорової творчості Віктора Степурка : дис. ... канд. мист. : 17.00.03. Прикарпатський нац. університет ім. В. Стефаника. Одеса, 2017. 224 с.

3. Верстюк I. «Степенні антифони XVII ст. світлої пам'яті святих Антонія та Феодосія Печерських» - під такою назвою пройшов творчий вечір сучасного композитора Віктора Степурка. Київ. URL: http:/arhiv.orthodoxy.org.ua/ uk/tserkva i kultura/2008/05/15/16088.html

4. Волошина $\overline{\mathrm{H}}$. Відомий і невідомий Віктор Степурко. Музика. 2005. № 4. С. 3-4.

5. Волошина Н. Духовна тематика в творчості українських композиторів 2-ої пол. XX ст. (на прикладі В. Степурка). Науковий вісник НМАУ : зб. статей. Київ, 2005. Вип. 36, кн. 1. С. 178-187.

6. Кушнірук О. Відомий і невідомий Віктор Степурко. Музика. 2005. № 3. С. 13-15.

7. Луніна А. Віктор Степурко: «Творче натхнення - це благодать або перст Божий...». Музика. 2012. № 6 (389). С. 24 -27.

8. Своим небесным покровителем композитор Виктор Степурко считает Димитрия Ростовского. Днепровская правда. 2012. 20 янв. URL: http://dpravda.org/svoim-nebesnympokrovitelem-kompozitor-viktor-stepurko-schitaet-dimitriyarostovskogo/.

9. Степанченко Г. Камерний хор «Київ» презентує. Культура і життя. 2012. 27 січня, № 4. С. 6.

10. Степурко В. Творчість - це розмова з Богом. Музика. 2007. № 4. С. 10-11.

\section{References:}

1. Afonina, O.V. (2007). Tvorchist V. Stepurka u kulturolohichnykh vymirakh suchasnoho muzychnoho mystetstva [Stepurko's creative work in culturological dimensions of contemporary music art]. Kyiv: Millennium [in Ukrainian].

2. Bardashevska, Ya. (2017). Obrazno-semantychni zasady khorovoi tvorchosti Viktora Stepurka [Figurative and semantic principles of Victor Stepurko's choral work]. Odesa [in Ukrainian].

3. Verstiuk, I. "Stepenni antyfony XVII st. svitloi pamiati sviatykh Antoniia ta Feodosiia Pecherskykh" - pid takoiu nazvoiu proishov tvorchyi vechir suchasnoho kompozytora Viktora Stepurka ["Powerful antiphons of XVII century of blessed 
memory of St. Anthony and St. Theodosius of the Caves" - by that name was the recital of a modern composer Viktor Stepurko]. Kyiv. Retrieved from: http://arhiv.orthodoxy.org.ua/uk/tserkva_i_kultura/2008/05/15/16088.html [in Ukrainian].

4. Voloshyna, N. (2005). Vidomyi i nevidomyi Viktor Stepurko [Well-known and unknown Viktor Stepurko]. Music. No. 4 [in Ukrainian].

5. Voloshyna, N. (2005). Dukhovna tematyka v tvorchosti ukrainskykh kompozytoriv 2-oi pol. XX st. (na prykladi V. Stepurka) [Religious themes in the works of Ukrainian composers of the second part of XX century (on the example of Viktor Stepurko). Kyiv [in Ukrainian].

6. Kushniruk, O. (2005). Vidomyi i nevidomyi Viktor Stepurko [Well-known and unknown Viktor Stepurko]. Music. No. 3 [in Ukrainian].

7. Lunina, A. (2012). Viktor Stepurko: “Tvorche natkhnennia - tse blahodat abo perst Bozhyi...” [Victor Stepurko: "Creative inspiration is a grace or a finger of God ..."] Music. No. 6 [in Ukrainian].

8. Dnieper truth (2012). Svoym nebesnym pokrovytelem kompozytor Vyktor Stepurko schytaet Dymytryia Rostovskoho [The composer Victor Stepurko considers Dimitry of Rostov as his patron saint]. Retrieved from: http://dpravda.org/svoimnebesnympokrovitelem-kompozitor-viktor-stepurko-schitaet-dimitriya-rostovskogo/ [in Ukrainian].

9. Stepanchenko, H. (2012). Kamernyi khor "Kyiv" prezentuie ["Kyiv" the chamber choir presents]. Culture and life. No. 4 [in Ukrainian].

10. Stepurko, V. (2007). Tvorchist - tse rozmova z Bohom [Creativity is a conversation with God]. Music. No. 4 [in Ukrainian].

DOI https://doi.org/10.51647/kelm.2020.3.2.5

\title{
РОЛЬ І МІСЦЕ ФУТУРИЗМУ У ТВОРЧОСТІ ПОЕТА, ПЕРЕКЛАДАЧА, ВЧЕНОГО МИКОЛИ БАЖАНА: КУЛЬТУРОЛОГІЧНИЙ АНАЛІЗ
}

\author{
Ольга Вернигоренко \\ провідний ведучий програми редакиії науково-пізнавальних передач \\ головної редакиії культурологічно-пізнавальних передач \\ ТО УР-3 «Культура» Акціонерного товариства \\ «Начіональна суспільна телерадіокомпанія Украӥни» (Київ, Украӥна) \\ ORCID ID: 0000-0001-5704-7924
}

\begin{abstract}
Анотація. Мета роботи - дослідити роль і місце футуризму як унікального філософсько-естетичного, соціальнополітичного, семантико-смислового та літературно-художнього феномену у творчості письменника і вченого Миколи Бажана. Методологія дослідження полягає в застосуванні загальнонаукових методів аналізу й синтезу, а також порівняльного, біографічного, психологічного методів. У роботі вперше подано культурологічно-філософське осмислення, відповідно до теорії історичного пізнання, розробленої Генріхом Ріккертом, місця і ролі футуризму в житті і творчості Миколи Бажана. Звернення в роботі до наукових напрацювань німецького філософа, одного з основоположників баденської школи неокантіанства Генріха Ріккерта, а саме до розробленої вченим теорії історичного пізнання як пізнання індивідуальної й неповторної реальності, яка центральним поняттям проголошує цінність, значно збагатило дослідження методологічно. Так, це дозволило поглянути на футуризм як на постійний пошук смислів і цінностей та смислу цінності загалом. Футуризм, саме в такому його розумінні відігравав надзвичайно важливу роль у творчості Миколи Бажана, вказав на силу мистецтва Слова, за яке варто було боротися, в це протистояння відбувалося на гострому лезі радянської тоталітарної системи, що пролягало між життям і смертю. Формальний відхід Миколи Бажана, який опинився в лещатах радянських спецслужб, від футуризму, можливо, якраз є проявом спроби збереження цінності, шансом шляхом власної самопожертви зберегти пам'ять про тих, хто не встояв у нерівній боротьбі.

Ключові слова: футуризм, футуристи-спіралісти, культура, культурний простір, цінність, зарозуміла мова,
\end{abstract} Микола Бажан.

\section{THE ROLE AND PLACE OF FUTURISM IN THE WORK OF THE POET, TRANSLATOR, SCIENTIST MYKOLA BAZHAN: CULTUROLOGICAL ANALYSIS}

\author{
Olha Vernyhorenko \\ Leading Presenter of the Program of Editing of Scientific and Cognitive Programs \\ of the Main Edition of Culturological and Cognitive Programs \\ CA Ch-3 "Culture" of the Joint-Stock Company \\ "National Public Television and Radio Company of Ukraine" (Kyiv, Ukraine) \\ ORCID ID: 0000-0001-5704-7924
}

\begin{abstract}
To explore the role and place of futurism as a unique philosophical and aesthetic, socio-political, semantic and literary-artistic phenomenon in the work of poet, writer and scientist Mykola Bazhan. The research methodology
\end{abstract}

